\title{
AGE AND SEX TRENDS IN ISCHAEMIC HEART DISEASE, CEREBROVASCULAR DISEASE, HYPERTENSION, AND DIABETES \\ A COMPARISON BETWEEN HOSPITAL DISCHARGE AND MORTALITY DATA
}

\author{
SIGISMOND DEUTSCHER, WILLIAM B. C. ROBERTSON AND ALLEN P. SMITH \\ Department of Preventive Medicine, Dalhousie University, Halifax, Nova Scotia, and \\ the Nova Scotia Hospital Insurance Commission
}

Much of our knowledge concerning patterns of disease in the general population is based on mortality statistics. However, trends observed in connexion with fatal forms of a disease do not necessarily apply to less severe forms. Thus, there is often a nced to supplement mortality data with more comprehensive information covering not only severe forms of illness but also milder ones.

The present study represents an attempt to secure information about morbidity by using data that are collected for routine purposes and are therefore available in great numbers, namely hospital discharge data generated through the Canadian Hospital Insurance Programme.

Age and sex patterns of in-patient morbidity for four inter-related conditions - ischaemic heart disease, cerebrovascular disease, hypertension, and diabetes-were examined and compared to patterns based on mortality statistics and to pertinent information from 'ad hoc' studies and nation-wide sampling surveys such as the United States National Health Survey.

\section{SOURCES OF DATA}

\section{MeTHodS}

Canadian provinces operate tax-supported insurance plans that provide universal coverage for in-patient hospital care. Together these plans form what is known as the Canadian Hospital Insurance Programme.

The information about in-patient morbidity contained in the present article is based on hospital discharge data. Each province collects and processes its data according to norms set by the central government in Ottawa. This ensures uniformity throughout the country.

Discharge rates for Canada as a whole were obtained from routinely published statistics. More detailed information was obtained for the province of Nova Scotia. It includes not only discharge rates but also rates of discharged persons and hospital fatality rates. These rates were calculated from? discharge data collected and stored by the Novaiv Scotia Hospital Insurance Commission, a provincialin agency that administers the Nova Scotia programme. Mortality rates were derived from routinelyo published vital statistics.

\section{Hospital USE in Nova Scotia}

The province of Nova Scotia has a population of $\overrightarrow{0}$ 750,000 , of which approximately one-third lives gn $\triangle$ Halifax county where the provincial capital, Halife is located. This county consists almost exclusive of the capital city and its suburbs. It contains only medical school in the province.

In the Halifax area, short-term in-patient care is provided in three teaching hospitals affiliated to the local medical school. By contrast, in the rest of the province one finds only relatively small, community type hospitals. Persons living in Halifax county use almost exclusively local facilities. Likewise, there is a tendency for residents of other parts of the provincep to use facilities that are located in their own of adjacent counties. However, not all patients in needs of hospital care are admitted to local hospitals. Some of the more complex cases, accounting for 10 to $15 \%$ of all admissions among residents of areas outside Halifax, are referred to the teaching hospitals mentioned before. Such referrals account for 20 to $30 \%$ of the bed occupancy in the afore-mentioned hospitals.

Partly as a result of this influx from outside the county, hospital beds are in relatively short supple in the Halifax area. Thus, if one takes into accountw occupancy by outside referrals, the ratio of beds to population for Halifax county is only about 4.5 per? 1,000 as compared to 6.5 per 1,000 , on the average for the rest of Nova Scotia. Because of this, physicians who practise in Halifax find it more difficulț to have their patients hospitalized than do those्ष practising in most other countries. 


\section{Retrieval of Data for Nova Scotia}

An abstract is completed for every in-patient on discharge from the hospital. It includes among other items: full name, date of birth, place of residence, date of discharge, duration of stay, a diagnostic summary, and information about outcome. Provision is made to record a primary and secondary diagnosis. The primary diagnosis, as a rule, refers to the condition that is most important in terms of utilization of hospital services. After being filled in at the hospital, the information goes to a central facility serving the whole province, where it is checked for gross inaccuracies, coded, punched on cards, and stored. Coding of clinical diagnoses is done according to the International Classification of Diseases.

Mean annual rates were computed from data collected for the period 1967-9. Retrieval, sorting, and other pertinent operations were done by computer. The data were sorted by age, sex, and place of residence. In order to determine the number of persons discharged, only one admission was ascertained for each person. This was done by matching the data on family name (first six characters), first initial, and date of birth, and then discarding all information relating to a person except that obtained during the last admission for a given calendar year. A separate operation was carried out for each of the four diagnostic categories under study.
Rates were calculated by relating numbers of discharges and of discharged persons to the population of Nova Scotia, and deaths in hospital to numbers of persons admitted. Because the conditions under study occur mainly in middle and old age, younger subjects were excluded from the analyses. For Nova Scotia, persons aged 35 and over were stratified into three broad age groupings: $35-54$, $55-69$, and 70 or over. The distribution of the population of Nova Scotia included in the study, by age group, sex, and place of residence is shown in Table I.

\section{Definition of Disease}

In order to reduce misclassifications, broad diagnostic categories were used. Thus, ischaemic heart disease refers to all diagnoses listed under 'Arteriosclerotic and Degenerative Heart Disease' (I.C.D. 420-422, 7th revision) and cerebrovascular disease to those listed under 'Vascular Lesions Affecting Central Nervous System' (I.C.D. 330-334). Hypertension includes 'Hypertensive Heart Disease' (I.C.D. 440-443) as well as 'Other Hypertensive Disease' (I.C.D. 444-447). Diabetes corresponds to I.C.D. 260.

\section{RESULTS \\ Frequency of Ischaemic Heart Disease by AGE AND SEX \\ Hospital discharge rates and mortality rates based on death records, by age and sex, together with their}

TABLE I

POPULATION OF NOVA SCOTIA* BY AGE, $\uparrow$ SEX, AND PLACE OF RESIDENCE $\ddagger$

\begin{tabular}{|c|c|c|c|c|c|c|}
\hline \multirow{2}{*}{ Age Group (years) } & \multicolumn{2}{|c|}{ Nova Scotia-All Counties } & \multicolumn{2}{|c|}{ Halifax County } & \multicolumn{2}{|c|}{ Counties other than Halifax } \\
\hline & Males & Females & Males & Females & Males & Females \\
\hline $\begin{array}{l}35-54 \\
55-69 \\
70+\end{array}$ & $\begin{array}{l}82,325 \\
40,213 \\
20,902\end{array}$ & $\begin{array}{l}82,931 \\
39,267 \\
24,836\end{array}$ & $\begin{array}{r}26,823 \\
10,342 \\
4,185\end{array}$ & $\begin{array}{r}27,170 \\
10,907 \\
5,587\end{array}$ & $\begin{array}{l}55,502 \\
29,871 \\
16,717\end{array}$ & $\begin{array}{l}55,761 \\
28,360 \\
19,249\end{array}$ \\
\hline Total & 143,440 & 147,034 & 41,350 & 43,664 & 102,090 & 103,370 \\
\hline
\end{tabular}

*Source: 1966 Census of Canada. Dominion Bureau of Statistics, Publ. No. 92-610. Queen's Printer, Ottawa

tIncludes only persons aged 35 and over

$\ddagger$ According to whether place of residence is in Halifax County

TABLE II

COMPARISON BETWEEN ANNUAL DISCHARGE RATES (1964)* AND DEATH RATES (1965)† FOR ISCHAEMIC HEART DISEASE, $\ddagger$ BY AGE AND SEX, AND MALE TO FEMALE RATIOS FOR RATES, CANADA

\begin{tabular}{|c|c|c|c|c|c|c|}
\hline \multirow{2}{*}{ Age Group (years) } & \multicolumn{2}{|c|}{ Discharges $\S$ per 1,000 Population } & \multicolumn{2}{|c|}{ Deaths per 1,000 Population } & \multicolumn{2}{|c|}{ Male to Female Ratios (Rates } \\
\hline & Males & Females & Males & Females & Discharges & Deaths \\
\hline $\begin{array}{l}25-44 \\
45-64 \\
65+ \\
\text { All ages } \|\end{array}$ & $\begin{array}{r}1.94 \\
15.20 \\
41.97 \\
12.67\end{array}$ & $\begin{array}{r}0.73 \\
7.35 \\
32.31 \\
7.86\end{array}$ & $\begin{array}{r}0.45 \\
5.27 \\
28.65 \\
6.43\end{array}$ & $\begin{array}{r}0.07 \\
1.39 \\
19.31 \\
3.45\end{array}$ & $\begin{array}{l}2 \cdot 66 \\
2 \cdot 07 \\
1 \cdot 30 \\
1 \cdot 61\end{array}$ & $\begin{array}{l}6.43 \\
3.79 \\
1.48 \\
1.86\end{array}$ \\
\hline
\end{tabular}

-Source: Hospital Morbidity, 1964. Dominion Bureau of Statistics, Publ. No. 82-526. Queen's Printer, Ottawa

tSource: Causes of Death, Canada, 1965. Dominion Bureau of Statistics, Publ. No. 84-203. Queen's Printer, Ottawa

II.C.D. 420-422, 7 th Revision, 1955

Based on primary diagnosis only

IIAdjusted to age distribution of population of Canada of both sexes 
respective male to female ratios, are shown in Table II, for Canada as a whole. Discharge rates were considerably higher than death rates. The difference between the two types of rate decreased with age for both sexes. Furthermore, male to female ratios were much higher for death than for discharge rates.

Clearly, the age and sex pattern seen for hospital morbidity is not the same as for mortality. There is a shift in age distribution towards the younger groups, and sex differentials, particularly among younger subjects, are less marked. This suggests that case fatality increases with age and is higher for men than women.

Data for Nova Scotia are presented in Tables III and IV and in Figures 1 and 2. Table III is similar in layout to Table II except for a somewhat different age arrangement. As before, morbidity and mortality differ in that, for the former, gradients between younger and older age groups are less sharp and sex ratios are less pronounced. The fact that morbidity rose less steeply with age than mortality is illustrated graphically in Figures 1 and 2.

Rates of persons discharged and proportions discharged alive are shown in Table IV. Neither age distribution nor sex ratios were appreciably changed after allowance was made for multiple admissions, because all three age groups and both sexes were $\mathcal{C}$ affected in the same fashion by the procedure.

As anticipated, hospital fatality rates increased $\frac{\pi}{\Phi}$ with age (Table IV). Contrary to what might have? been expected on the basis of previously observed $\overrightarrow{\vec{F}}$ differences between discharge and death rates? (Tables II and III), hospital fatality rates were only등 slightly higher for males than for females. A possible $\frac{\bar{c}}{\bar{c}}$. explanation for this apparent discrepancy is that $\frac{\widetilde{\sigma}}{\widetilde{\sigma}}$ sudden deaths, which are more common among males, tend to occur outside the hospital. Therefore, it seems likely that real differences in case fatality $\vec{O}$ rate between men and women are larger than: indicated in the present data.

\section{Frequency of Cerebrovascular Disease by Age AND SeX}

As was the case for ischaemic heart disease, on morbidity rose less sharply with age than mortalityoo (Figs 3 and 4; Tables V and VI).

Sex ratios for hospital morbidity were mostly? above unity, suggesting that males have a somewhat $\vec{z}$ higher risk of developing cerebrovascular diseasen than females. For unexplained reasons, this trend is not visible in the mortality data.

Table VII indicates that the increased morbid $y$.

TABLE III

COMPARISON BETWEEN MEAN ANNUAL DISCHARGE RATES (1967-9) AND DEATH RATES (1966-8)* FOR ISCHAEMIC HEART DISEASE, $\dagger$ BY AGE AND SEX, AND MALE TO FEMALE RATIOS FOR RATES, NOVA SCOTIA

\begin{tabular}{|c|c|c|c|c|c|c|c|c|c|c|}
\hline \multirow{3}{*}{$\underset{\text { (years) }}{\text { Age Group }}$} & \multicolumn{4}{|c|}{ Discharges +} & \multicolumn{4}{|c|}{ Deaths } & \multirow{2}{*}{\multicolumn{2}{|c|}{$\begin{array}{c}\text { Male to Female Ratios } \\
\text { (Rates) }\end{array}$}} \\
\hline & \multicolumn{2}{|c|}{ Males } & \multicolumn{2}{|c|}{ Females } & \multicolumn{2}{|c|}{ Males } & \multicolumn{2}{|c|}{ Females } & & \\
\hline & No. & $\begin{array}{c}\text { Rate } \\
\text { per } 1,000\end{array}$ & No. & $\begin{array}{c}\text { Rate } \\
\text { per } 1,000\end{array}$ & No. & $\begin{array}{c}\text { Rate } \\
\text { per } 1,000\end{array}$ & No. & $\begin{array}{c}\text { Rate } \\
\text { per } 1,000\end{array}$ & Discharges & Deaths \\
\hline $\begin{array}{l}35-54 \\
55-69 \\
70+ \\
\text { All ages } \S\end{array}$ & $\begin{array}{r}689 \\
1,149 \\
1,043 \\
2,881\end{array}$ & $\begin{array}{r}8 \cdot 37 \\
28 \cdot 57 \\
49 \cdot 90 \\
20 \cdot 44\end{array}$ & $\begin{array}{r}224 \\
617 \\
951 \\
1,792\end{array}$ & $\begin{array}{r}2.70 \\
15 \cdot 71 \\
38.29 \\
11.86\end{array}$ & $\begin{array}{r}128 \\
387 \\
767 \\
1,282\end{array}$ & $\begin{array}{r}1 \cdot 55 \\
9 \cdot 62 \\
36 \cdot 69 \\
9 \cdot 29\end{array}$ & $\begin{array}{r}30 \\
130 \\
631 \\
791\end{array}$ & $\begin{array}{r}0 \cdot 36 \\
3 \cdot 31 \\
25 \cdot 41 \\
5 \cdot 11\end{array}$ & $\begin{array}{l}3 \cdot 10 \\
1.82 \\
1.30 \\
1.72\end{array}$ & $\begin{array}{l}4.31 \\
2.91 \\
1.44 \\
1.82\end{array}$ \\
\hline
\end{tabular}

*Source: Annual Report of The Registrar General, Vital Statistics, 1966-68. Department of Public Health, Nova Scotia. Queen's Printer †I.C.D. 420-422, 7th Revision, 1955

tBased on primary diagnoses only

§Age standardized

TABLE IV

MEAN ANNUAL RATES OF DISCHARGED PERSONS (1967-69) FOR ISCHAEMIC HEART DISEASE* BY AGE AND SEX, MALE TO FEMALE RATIOS FOR RATES, AND PROPORTIONS OF PATIENTS DISCHARGED ALIVE, NOVA SCOTIA

\begin{tabular}{|c|c|c|c|c|c|c|c|}
\hline \multirow{3}{*}{$\begin{array}{l}\text { Age Group } \\
\text { (years) }\end{array}$} & \multicolumn{4}{|c|}{ Persons Discharged $\dagger$} & \multirow{3}{*}{$\begin{array}{l}\text { Male to Female } \\
\text { Ratios (Rates) }\end{array}$} & \multirow{2}{*}{\multicolumn{2}{|c|}{ Percent Discharged Alive }} \\
\hline & \multicolumn{2}{|c|}{ Males } & \multicolumn{2}{|c|}{ Females } & & & \\
\hline & No. & Rate per 1,000 & No. & Rate per 1,000 & & Males & Females \\
\hline $\begin{array}{l}35-54 \\
55-69 \\
70+ \\
\text { All ages: }\end{array}$ & $\begin{array}{r}582 \\
979 \\
900 \\
2,461\end{array}$ & $\begin{array}{r}7 \cdot 07 \\
24 \cdot 35 \\
43.06 \\
17 \cdot 47\end{array}$ & $\begin{array}{r}203 \\
529 \\
831 \\
1,563\end{array}$ & $\begin{array}{r}2.45 \\
13.47 \\
33.46 \\
10 \cdot 35\end{array}$ & $\begin{array}{l}2 \cdot 89 \\
1 \cdot 81 \\
1 \cdot 29 \\
1.69\end{array}$ & $\begin{array}{l}92 \\
85 \\
72 \\
86\end{array}$ & $\begin{array}{l}94 \\
87 \\
77 \\
89\end{array}$ \\
\hline
\end{tabular}

*I.C.D. 420-422, 7th Revision, 1955

+ Based on primary diagnosis only

†Age standardized 

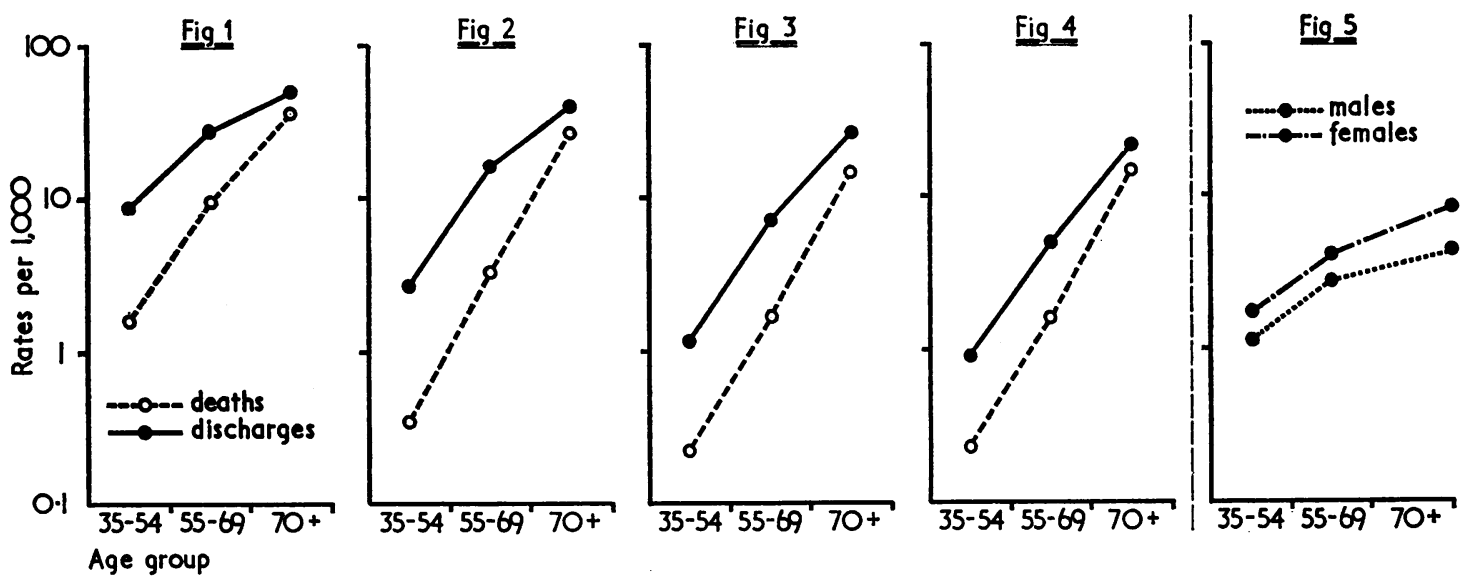

Fig. 1.-Increase with age of mortality (based on vital statistics) and hospital morbidity due to ischaemic heart disease. Males aged 35 and over, Nova Scotia.

FIG. 2. - Increase with age of mortality (based on vital statistics) and hospital morbidity due to ischaemic heart disease. Females aged 35 and over, Nova Scotia.

FIG. 3.-Increase with age of mortality (based on vital statistics) and

observed among men in relation to women cannot be explained by a higher frequency of multiple admissions.

\section{Frequency of Hypertension AND Diabetes by AGE AND SEX}

Hospital morbidity due to hypertension was higher for women than for men (Tables VIII to X). Among men, the increase (on a logarithmic scale) was less marked after middle age than before, whereas for women the rate of increase was about the same for the two age intervals (Fig. 5); because of this, male to female differences tended to increase with age.

Mortality ascribed to hypertension was higher for women than for men in the oldest age group only (Tables VIII and IX).

Similar results were observed for diabetes (Tables XI to XIII). Male to female ratios were below unity hospital morbidity due to cerebrovascular disease. Males aged 35 and over, Nova Scotia.

FIG. 4 -Increase with age of mortality (based on vital statistics) and hospital morbidity due to cerebrovascular disease. Females aged 35 and over, Nova Scotia.

FIG. 5.-Increase with age of hospital morbidity due to hypertension among males and females, Nova Scotia.

in all age groups, and the trend was more pronounced for older persons than for younger ones.

\section{Possibility of a Bias ARISING fROM THE USE OF Different Diagnostic Criteria for Men aNd WOMEN}

The discharge rates shown so far refer to primary diagnoses; secondary diagnoses were excluded from the calculations. Sometimes, however, patients are hospitalized because of symptoms resulting from more than one illness. It may be difficult in these circumstances to single out one condition as the primary diagnosis. It could be that, in doubtful situations, the criteria used for this purpose vary according to the sex of the patient. This might lead, for a given condition, to over-diagnosis in one sex accompanied by under-diagnosis in the other.

The results shown in Table XIV suggest that such a bias did in fact influence our data. A higher

TABLE V

COMPARISON BETWEEN ANNUAL DISCHARGE RATES (1964)* AND DEATH RATES (1965) + FOR CEREBROVASCULAR DISEASE, BY AGE AND SEX, AND MALE TO FEMALE RATIOS FOR RATES, CANADA

\begin{tabular}{|c|c|c|c|c|c|c|}
\hline \multirow{2}{*}{ Age Group (years) } & \multicolumn{2}{|c|}{ Discharges $\S$ per 1,000 Population } & \multicolumn{2}{|c|}{ Deaths per 1,000 Population } & \multicolumn{2}{|c|}{ Male to Female Ratios (Rates) } \\
\hline & Males & Females & Males & Females & Discharges & Deaths \\
\hline $\begin{array}{l}25-44 \\
45-64 \\
65+ \\
\text { All ages } \|\end{array}$ & $\begin{array}{r}0.30 \\
2.50 \\
16.29 \\
3.50\end{array}$ & $\begin{array}{r}0.31 \\
1.96 \\
14.29 \\
3.01\end{array}$ & $\begin{array}{l}0.06 \\
0.64 \\
8.85 \\
1.60\end{array}$ & $\begin{array}{l}0.06 \\
0.55 \\
8.86 \\
1.57\end{array}$ & $\begin{array}{l}0.97 \\
1 \cdot 28 \\
1 \cdot 14 \\
1 \cdot 16\end{array}$ & $\begin{array}{l}1.00 \\
1.16 \\
1.00 \\
1.02\end{array}$ \\
\hline
\end{tabular}

-Source: Hospital Morbidity, 1964. Dominion Bureau of Statistics, Publ. No. 82-526. Queen's Printer, Ottawa

+Source: Causes of Death, Canada, 1965. Dominion Bureau of Statistics, Publ. No. 84-203. Queen's Printer, Ottawa

II.C.D. 330-334, 7th Revision, 1955

Based on primary diagnoses only

\|Adjusted to age distribution of population of Canada of both sexes 
TABLE VI

COMPARISON BETWEEN MEAN ANNUAL DISCHARGE RATES (1967-9) AND DEATH RATES (1966-8)* FOR CEREBROVASCULAR DISEASE, $\dagger$ BY AGE AND SEX, AND MALE TO FEMALE RATIOS FOR RATES, NOVA SCOTIA

\begin{tabular}{|c|c|c|c|c|c|c|c|c|c|c|}
\hline \multirow{3}{*}{$\begin{array}{l}\text { Age Group } \\
\text { (years) }\end{array}$} & \multicolumn{4}{|c|}{ Discharges $\ddagger$} & \multicolumn{4}{|c|}{ Deaths } & \multirow{2}{*}{\multicolumn{2}{|c|}{$\begin{array}{l}\text { Male to Female Ratios } \\
\text { (Rates) }\end{array}$}} \\
\hline & \multicolumn{2}{|c|}{ Males } & \multicolumn{2}{|c|}{ Females } & \multicolumn{2}{|c|}{ Males } & \multicolumn{2}{|c|}{ Females } & & \\
\hline & No. & $\begin{array}{c}\text { Rate } \\
\text { per } 1,000\end{array}$ & No. & $\begin{array}{c}\text { Rate } \\
\text { per } 1,000\end{array}$ & No. & $\begin{array}{c}\text { Rate } \\
\text { per } 1,000\end{array}$ & No. & $\begin{array}{c}\text { Rate } \\
\text { per } 1,000\end{array}$ & Discharges & Deaths \\
\hline $\begin{array}{l}35-54 \\
55-69 \\
70+ \\
\text { All ages } \S\end{array}$ & $\begin{array}{r}93 \\
277 \\
543 \\
913\end{array}$ & $\begin{array}{r}1.13 \\
6.89 \\
25.98 \\
6.62\end{array}$ & $\begin{array}{r}75 \\
193 \\
515 \\
783\end{array}$ & $\begin{array}{r}0.90 \\
4.91 \\
20.74 \\
5.12\end{array}$ & $\begin{array}{r}18 \\
66 \\
287 \\
371\end{array}$ & $\begin{array}{r}0.22 \\
1.64 \\
13.73 \\
2.74\end{array}$ & $\begin{array}{r}19 \\
63 \\
352 \\
434\end{array}$ & $\begin{array}{r}0 \cdot 23 \\
1.60 \\
14 \cdot 17 \\
2 \cdot 80\end{array}$ & $\begin{array}{l}1.26 \\
1.40 \\
1.25 \\
1.29\end{array}$ & $\begin{array}{l}0.96 \\
1.02 \\
0.97 \\
0.98\end{array}$ \\
\hline
\end{tabular}

-Source: Annual Report of The Registrar General, Vital Statistics, 1966-68. Department of Public Health, Nova Scotia. Queen's Printer $\overrightarrow{0}$ II.C.D. 330-334, 7th Revision, 1955

$\ddagger$ Based on primary diagnoses only

§age standardized

TABLE VII

MEAN ANNUAL RATES OF DISCHARGED PERSONS (1967-9) FOR CEREBROVASCULAR DISEASE* BY AGE AND SEX, MALE TO FEMALE RATIOS FOR RATES, AND PROPORTIONS OF PATIENTS DISCHARGED ALIVE, NOVA SCOTIA

\begin{tabular}{|c|c|c|c|c|c|c|c|}
\hline \multirow{3}{*}{$\begin{array}{l}\text { Age Group } \\
\text { (years) }\end{array}$} & \multicolumn{4}{|c|}{ Persons Discharged $\dagger$} & \multirow{3}{*}{$\begin{array}{l}\text { Male to Female } \\
\text { Ratios (Rates) }\end{array}$} & \multirow{2}{*}{\multicolumn{2}{|c|}{ Percent Discharged Alive }} \\
\hline & \multicolumn{2}{|c|}{ Males } & \multicolumn{2}{|c|}{ Females } & & & \\
\hline & No. & Rate per 1,000 & No. & Rate per 1,000 & & Males & Females \\
\hline $\begin{array}{l}\text { 35-54 } \\
55-69 \\
70+ \\
\text { All agest }\end{array}$ & $\begin{array}{r}74 \\
238 \\
496 \\
808\end{array}$ & $\begin{array}{r}0.90 \\
5.92 \\
23.73 \\
5.87\end{array}$ & $\begin{array}{r}63 \\
169 \\
467 \\
699\end{array}$ & $\begin{array}{r}0 \cdot 76 \\
4 \cdot 30 \\
18 \cdot 80 \\
4.57\end{array}$ & $\begin{array}{l}1 \cdot 18 \\
1.38 \\
1.26 \\
1.28\end{array}$ & $\begin{array}{l}77 \\
79 \\
62 \\
75\end{array}$ & $\begin{array}{l}79 \\
77 \\
66 \\
76\end{array}$ \\
\hline
\end{tabular}

I.C.D. 330-334, 7th Revision, 1955

tBased on primary diagnoses only

$\ddagger$ Age standardized

TABLE VIII

COMPARISON BETWEEN ANNUAL DISCHARGE RATES (1964) AND DEATH RATES (1965) FOR HYPERTENSION, BY AGE AND SEX, AND MALE TO FEMALE RATIOS FOR RATES, CANADA

\begin{tabular}{|c|c|c|c|c|c|c|}
\hline \multirow{2}{*}{ Age Group (years) } & \multicolumn{2}{|c|}{ Discharges $\$$ per 1,000 Population } & \multicolumn{2}{|c|}{ Deaths per 1,000 Population } & \multicolumn{2}{|c|}{ Male to Female Ratios (Rates) } \\
\hline & Males & Females & Males & Females & Discharges & Deaths \\
\hline $\begin{array}{l}25-44 \\
45-64 \\
65+ \\
\text { All ages } \|\end{array}$ & $\begin{array}{l}0.56 \\
2.21 \\
5.58 \\
1.90\end{array}$ & $\begin{array}{r}0.69 \\
3.95 \\
10.68 \\
3.35\end{array}$ & $\begin{array}{l}0.01 \\
0.17 \\
1.59 \\
0.31\end{array}$ & $\begin{array}{l}0.01 \\
0.12 \\
2.02 \\
0.35\end{array}$ & $\begin{array}{l}0.81 \\
0.56 \\
0.52 \\
0.57\end{array}$ & $\begin{array}{l}1.00 \\
1.42 \\
0.79 \\
0.89\end{array}$ \\
\hline
\end{tabular}

-Source: Hospital Morbidity, 1964. Dominion Bureau of Statistics, Publ. No. 82-526. Queen's Printer, Ottawa

tSource: Causes of Death, Canada, 1965. Dominion Bureau of Statistics, Publ. No. 84-203. Queen's Printer, Ottawa

I.C.D. 440-447, 7th Revision, 1955

§Based on primary diagnoses, only

IAdjusted to age distribution of population of Canada of both sexes

TABLE IX

COMPARISON BETWEEN MEAN ANNUAL DISCFIARGB RATES (1967-9) AND DBATH RATES (1966-8) FOR FYPERTENSION, $\dagger$ BY AGE AND SEX, AND MALE TO FEMALE RATIOS FOR RATES, NOVA SCOTIA

\begin{tabular}{|c|c|c|c|c|c|c|c|c|c|c|}
\hline \multirow{3}{*}{$\begin{array}{l}\text { Age Group } \\
\text { (years) }\end{array}$} & \multicolumn{4}{|c|}{ Discharges! } & \multicolumn{4}{|c|}{ Deaths } & \multirow{2}{*}{\multicolumn{2}{|c|}{$\begin{array}{l}\text { Malo to Female Ratios } \\
\text { (Rates) }\end{array}$}} \\
\hline & \multicolumn{2}{|c|}{ Males } & \multicolumn{2}{|c|}{ Females } & \multicolumn{2}{|c|}{ Males } & \multicolumn{2}{|c|}{ Females } & & \\
\hline & No. & $\begin{array}{c}\text { Rate } \\
\text { per } 1,000\end{array}$ & No. & $\begin{array}{c}\text { Rate } \\
\text { per } 1,000\end{array}$ & No. & $\begin{array}{c}\text { Rate } \\
\text { per } 1,000\end{array}$ & No. & $\begin{array}{c}\text { Rate } \\
\text { per } 1,000\end{array}$ & Discharges & Deaths \\
\hline $\begin{array}{l}35-54 \\
55-69 \\
70+ \\
\text { All ages } \$\end{array}$ & $\begin{array}{r}96 \\
125 \\
90 \\
311\end{array}$ & $\begin{array}{l}1 \cdot 17 \\
3 \cdot 11 \\
4 \cdot 31 \\
2 \cdot 20\end{array}$ & $\begin{array}{l}167 \\
170 \\
222 \\
559\end{array}$ & $\begin{array}{l}2.01 \\
4.33 \\
8.94 \\
3 \cdot 74\end{array}$ & $\begin{array}{r}3 \\
11 \\
43 \\
57\end{array}$ & $\begin{array}{l}0.04 \\
0.27 \\
2.06 \\
0.42\end{array}$ & $\begin{array}{r}2 \\
10 \\
59 \\
71\end{array}$ & $\begin{array}{l}0.02 \\
0.25 \\
2.38 \\
0.45\end{array}$ & $\begin{array}{l}0.58 \\
0.72 \\
0.48 \\
0.59\end{array}$ & $\begin{array}{l}2.00 \\
1.08 \\
0-87 \\
0.93\end{array}$ \\
\hline
\end{tabular}

- Source: Annual Report of The Registrar General, Vital Statistics, 1966-68. Department of Public Fealth, Nova Scotia. Queen's Printer, 0 Halifax

tI.C.D. 440-447, 7th Revision, 1955

fBased on primary diagnoses only

\$ABe standardized 
TABLE X

MEAN ANNUAL RATES OF DISCHARGED PERSONS (1967-9) FOR HYPERTENSION* BY AGE AND SEX, MALE TO FEMALE RATIOS FOR RATES, AND PROPORTIONS OF PATIENTS DISCHARGED ALIVE, NOVA SCOTIA

\begin{tabular}{|c|c|c|c|c|c|c|c|}
\hline \multirow{3}{*}{$\begin{array}{l}\text { Age Group } \\
\text { (years) }\end{array}$} & \multicolumn{4}{|c|}{ Persons Discharged $\dagger$} & \multirow{3}{*}{$\begin{array}{l}\text { Male to Female } \\
\text { Ratios( Rates) }\end{array}$} & \multirow{2}{*}{\multicolumn{2}{|c|}{ Percent Discharged Alive }} \\
\hline & \multicolumn{2}{|c|}{ Males } & \multicolumn{2}{|c|}{ Females } & & & \\
\hline & No. & Rate per 1,000 & No. & Rate per 1,000 & & Males & Females \\
\hline $\begin{array}{l}35-54 \\
55-69 \\
70+ \\
\text { All ages }\end{array}$ & $\begin{array}{r}89 \\
114 \\
86 \\
289\end{array}$ & $\begin{array}{l}1.08 \\
2.83 \\
4.11 \\
2.04\end{array}$ & $\begin{array}{l}146 \\
155 \\
202 \\
503\end{array}$ & $\begin{array}{l}1 \cdot 76 \\
3 \cdot 95 \\
8 \cdot 13 \\
3 \cdot 36\end{array}$ & $\begin{array}{l}0.61 \\
0.72 \\
0.51 \\
0.61\end{array}$ & $\begin{array}{l}96 \\
98 \\
90 \\
95\end{array}$ & $\begin{array}{l}99 \\
98 \\
93 \\
97\end{array}$ \\
\hline
\end{tabular}

*I.C.D. 440-447, 7th Revision, 1955

†Based on primary diagnoses only

$¥$ Age standardized

TABLE XI

COMPARISON BETWEEN ANNUAL DISCHARGE RATES (1964)* AND DEATH RATES (1965)† FOR DIABETES, BY AGE AND SEX, AND MALE TO FEMALE RATIOS FOR RATES, CANADA

\begin{tabular}{|c|c|c|c|c|c|c|}
\hline \multirow{2}{*}{ Age Group (years) } & \multicolumn{2}{|c|}{ Discharges $\S$ per 1,000 Population } & \multicolumn{2}{|c|}{ Deaths per 1,000 Population } & \multicolumn{2}{|c|}{ Male to Female Ratios (Rates) } \\
\hline & Males & Females & Males & Females & Discharges & Deaths \\
\hline $\begin{array}{l}25-44 \\
45-64 \\
65+ \\
\text { All ages } \|\end{array}$ & $\begin{array}{l}1 \cdot 08 \\
3 \cdot 56 \\
8.59 \\
3.09\end{array}$ & $\begin{array}{r}1 \cdot 17 \\
5 \cdot 03 \\
12 \cdot 69 \\
4 \cdot 28\end{array}$ & $\begin{array}{l}0.03 \\
0.15 \\
1.06 \\
0.23\end{array}$ & $\begin{array}{l}0 \cdot 01 \\
0 \cdot 17 \\
1 \cdot 34 \\
0 \cdot 27\end{array}$ & $\begin{array}{l}0.92 \\
0.71 \\
0.68 \\
0.72\end{array}$ & $\begin{array}{l}3.00 \\
0.88 \\
0.79 \\
0.85\end{array}$ \\
\hline
\end{tabular}

-Source: Hospital Morbidity, 1964. Dominion Bureau of Statistics, Publ. No. 82-526. Queen's Printer, Ottawa

tSource: Causes of Death, Canada, 1965. Dominion Buerau of Statistics, Publ. No. 84-203. Queen's Printer, Ottawa

II.C.D. 260, 7th Revision, 1955

Based on primary diagnoses only

\|IAdjusted to age distribution of population of Canada of both sexes

TABle XII

COMPARISON BETWEEN MEAN ANNUAL DISCHARGE RATES (1967-9) AND DEATH RATES (1966-8)* FOR DIABETES, $\dagger$ BY AGE AND SEX, AND MALE TO FEMALE RATIOS FOR RATES, NOVA SCOTIA

\begin{tabular}{|c|c|c|c|c|c|c|c|c|c|c|}
\hline \multirow{3}{*}{$\begin{array}{l}\text { Age Group } \\
\text { (years) }\end{array}$} & \multicolumn{4}{|c|}{ Discharges } & \multicolumn{4}{|c|}{ Deaths } & \multirow{2}{*}{\multicolumn{2}{|c|}{$\begin{array}{c}\text { Male to Female Ratio } \\
\text { (Rates) }\end{array}$}} \\
\hline & \multicolumn{2}{|c|}{ Males } & \multicolumn{2}{|c|}{ Females } & \multicolumn{2}{|c|}{ Males } & \multicolumn{2}{|c|}{ Females } & & \\
\hline & No. & $\begin{array}{c}\text { Rate } \\
\text { per } 1,000\end{array}$ & No. & $\begin{array}{c}\text { Rate } \\
\text { per } 1,000\end{array}$ & No. & $\begin{array}{c}\text { Rate } \\
\text { per } 1,000\end{array}$ & No. & $\begin{array}{c}\text { Rate } \\
\text { per } 1,000\end{array}$ & Discharges & Deaths \\
\hline $\begin{array}{l}35-54 \\
55-69 \\
70+ \\
\text { All ages } \$\end{array}$ & $\begin{array}{l}159 \\
212 \\
182 \\
553\end{array}$ & $\begin{array}{l}1.93 \\
5.27 \\
8.71 \\
3.91\end{array}$ & $\begin{array}{l}209 \\
359 \\
350 \\
918\end{array}$ & $\begin{array}{r}2 \cdot 52 \\
9 \cdot 14 \\
14 \cdot 09 \\
6 \cdot 15\end{array}$ & $\begin{array}{r}6 \\
16 \\
33 \\
55\end{array}$ & $\begin{array}{l}0.07 \\
0.40 \\
1.58 \\
0.40\end{array}$ & $\begin{array}{r}5 \\
22 \\
50 \\
77\end{array}$ & $\begin{array}{l}0.06 \\
0.56 \\
2.01 \\
0.50\end{array}$ & $\begin{array}{l}0.77 \\
0.58 \\
0.62 \\
0.64\end{array}$ & $\begin{array}{l}1.17 \\
0.71 \\
0.79 \\
0.80\end{array}$ \\
\hline
\end{tabular}

-Source: Annual Report of The Registrar General, Vital Statistics, 1966-68. Department of Public Health, Nova Scotia. Queen's Printer, Halifax

II.C.D. 260, 7th Revision, 1955

tBased on primary diagnoses only

\$Age standardized

TABle XIII

MEAN ANNUAL RATES OF DISCHARGED PERSONS (1967-9) FOR DIABETES* BY AGE AND SEX, MALE TO FEMALE RATIOS FOR RATES, AND PROPORTIONS OF PATIENTS DISCHARGED ALIVE, NOVA SCOTIA

\begin{tabular}{|c|c|c|c|c|c|c|c|}
\hline \multirow{3}{*}{$\begin{array}{l}\text { Age Group } \\
\text { (years) }\end{array}$} & \multicolumn{4}{|c|}{ Persons Discharged $\dagger$} & \multirow{3}{*}{$\begin{array}{l}\text { Male to Female } \\
\text { Ratios (Rates) }\end{array}$} & \multirow{2}{*}{\multicolumn{2}{|c|}{ Percent Discharged Alive }} \\
\hline & \multicolumn{2}{|c|}{ Males } & \multicolumn{2}{|c|}{ Females } & & & \\
\hline & No. & Rate per 1,000 & No. & Rate per 1,000 & & Males & Females \\
\hline $\begin{array}{l}35-54 \\
55-69 \\
70+ \\
\text { All agest }\end{array}$ & $\begin{array}{l}126 \\
175 \\
149 \\
450\end{array}$ & $\begin{array}{l}1 \cdot 53 \\
4 \cdot 35 \\
7 \cdot 13 \\
3 \cdot 18\end{array}$ & $\begin{array}{l}172 \\
296 \\
285 \\
753\end{array}$ & $\begin{array}{r}2.07 \\
7.54 \\
11.48 \\
5.05\end{array}$ & $\begin{array}{l}0.74 \\
0.68 \\
0.62 \\
0.63\end{array}$ & $\begin{array}{l}98 \\
98 \\
94 \\
97\end{array}$ & $\begin{array}{l}99 \\
98 \\
95 \\
98\end{array}$ \\
\hline
\end{tabular}

I.C.D. 260, 7th Revision, 1955

tBased on primary diagnoses only

$\$$ Age standardized 
proportion of all diagnoses of ischaemic heart disease were listed as being primary in men than in women. Rates for men may thus have been artificially inflated. A similar distortion could have occurred for cerebrovascular disease. By contrast, in the cases of hypertension and diabetes, the women appear to have been favoured.

If discharge rates for Nova Scotia are recalculated on the basis of all listed diagnoses instead of just primary ones, age-adjusted male to female ratios read as follows: 1.60 for ischaemic heart disease, 1.28 for cerebrovascular disease, 0.61 for hypertension, and 0.71 for diabetes, as compared to 1.72 , $1 \cdot 29,0.59$, and 0.64 , respectively, on the basis of primary diagnoses only. Clearly, if a bias occurred, its effect on the data must have been small.

\section{Morbidity Patterns in Areas with High and \\ Low LeVels of Hospital Utilization}

Measurements of morbidity based on hospital data are known to be highly dependent upon prevailing patterns of medical care and hospital use. This is well illustrated by the results shown in Tables XV and XVI. The rates of discharged persons for Halifax, where it is more difficult to have a patient hospitalized, were noticeably lower than for 8 the rest of the province. Furthermore, the proportion 3 of patients discharged alive was also smaller in $\stackrel{\mathbb{Q}}{\circ}$ Halifax (Table XVII). Thus, the data strongly suggest that the increase in hospital morbidity $\stackrel{\vec{s}}{\rightarrow}$ observed outside Halifax was due, in part at least, to the admission of less severe cases which would $\bar{\sigma}$ presumably not have been treated as in-patients had $\frac{\bar{p}}{\overrightarrow{0}}$ they lived in Halifax.

While there were no appreciable differences in age distribution between the two sets of data (Tables $\vec{A}$ $\mathrm{XV}$ and $\mathrm{XVI}$ ), male to female ratios for ischaemic heart disease, hypertension, diabetes, and, less $\vec{\omega}$ clearly, for cerebrovascular disease, were higher in $\stackrel{\circ}{.}$ Halifax than in the other counties (Table XVIII). Taken at their face value, the results seem to indicate $\stackrel{\rho}{\vec{N}}$ that women who are affected by these conditions or tend to develop less severe forms of illness than men. It should be kept in mind, however, that such $\stackrel{\infty}{\oplus}$ differences in sex ratios may merely reflect differences 음 in hospital use between men and women. It is interesting to recall in this connexion that in Barrow proportionately more women than men were

TABLE XIV

PROPORTIONS OF DIAGNOSES LISTED AS PRIMARY FOR ISCHAEMIC HEART DISEASE, CEREBROVASCULAR DISEASE, HYPERTENSION, AND DIABETES, BY AGE AND SEX, NOVA SCOTIA

\begin{tabular}{|c|c|c|c|c|c|c|c|c|c|c|c|c|c|c|c|c|}
\hline \multirow{3}{*}{$\begin{array}{c}\text { Diagnosis } \\
\text { on Discharge }\end{array}$} & \multicolumn{8}{|c|}{ Males } & \multicolumn{8}{|c|}{ Females } \\
\hline & \multicolumn{2}{|c|}{$35-54$} & \multicolumn{2}{|c|}{$55-69$} & \multicolumn{2}{|c|}{$\mathbf{7 0}+$} & \multicolumn{2}{|c|}{ All Ages* } & \multicolumn{2}{|c|}{$35-54$} & \multicolumn{2}{|c|}{$55-69$} & \multicolumn{2}{|c|}{$70+$} & \multicolumn{2}{|c|}{ All Ages* } \\
\hline & $\begin{array}{l}\text { All } \\
\text { Listed } \\
\text { (No.) }\end{array}$ & $\underset{(\%)}{\text { Pri- }}$ & $\begin{array}{l}\text { All } \\
\text { Listed } \\
\text { (No.) }\end{array}$ & $\underset{(\%)}{\text { Pri- }}$ & $\begin{array}{l}\text { All } \\
\text { Listed } \\
\text { (No.) }\end{array}$ & $\underset{(\%)}{\text { Pri- }}$ & $\begin{array}{l}\text { All } \\
\text { Listed } \\
\text { (No.) }\end{array}$ & $\underset{\text { mary }}{\text { Pri- }}$ & $\begin{array}{l}\text { All } \\
\text { Liste } \\
\text { (No. }\end{array}$ & $\underset{(\%)}{\text { Pri- }}$ & $\begin{array}{c}\text { All } \\
\text { Listed } \\
\text { (No.) }\end{array}$ & $\underset{(\%)}{\text { Pri- }}$ & $\begin{array}{l}\text { All } \\
\text { Listed } \\
\text { (No.) }\end{array}$ & $\underset{(\%)}{\text { Pri- }}$ & $\begin{array}{l}\text { All } \\
\text { Listed } \\
\text { (No.) }\end{array}$ & $\underset{(\%)}{\text { Pri- }}$ \\
\hline $\begin{array}{l}\text { Ischaemic heart disease } \\
\text { (I.C.D. 420-422) }\end{array}$ & 840 & 82 & 1,492 & 77 & 1,512 & 69 & 3,841 & 75 & 307 & 73 & 857 & 72 & 1,149 & 67 & 2,597 & 70 \\
\hline $\begin{array}{l}\text { Cerebrovascular disease } \\
\text { (I.C.D. 330-334) }\end{array}$ & 106 & 88 & 330 & 84 & 670 & 81 & 1,113 & 83 & 86 & 87 & 238 & 81 & 652 & 79 & 967 & 80 \\
\hline $\begin{array}{l}\text { Hypertension } \\
\quad \text { (I.C.D. 440-447) } \\
\text { Diabetes (I.C.D. 260) }\end{array}$ & $\begin{array}{l}157 \\
284\end{array}$ & $\begin{array}{l}61 \\
56\end{array}$ & $\begin{array}{l}236 \\
442\end{array}$ & $\begin{array}{l}53 \\
48\end{array}$ & $\begin{array}{l}173 \\
404\end{array}$ & $\begin{array}{l}52 \\
45\end{array}$ & $\begin{array}{r}565 \\
1,129\end{array}$ & $\begin{array}{l}55 \\
49\end{array}$ & $\begin{array}{l}274 \\
343\end{array}$ & $\begin{array}{l}61 \\
61\end{array}$ & $\begin{array}{l}315 \\
653\end{array}$ & $\begin{array}{l}54 \\
55\end{array}$ & $\begin{array}{l}389 \\
686\end{array}$ & $\begin{array}{l}57 \\
51\end{array}$ & $\begin{array}{r}981 \\
1,700\end{array}$ & $\begin{array}{l}57 \\
55\end{array}$ \\
\hline
\end{tabular}

*Age standardized

TABLE XV

COMPARISON BETWEEN MEAN ANNUAL RATES OF MALES DISCHARGED IN HALIFAX COUNTY AND IN COUNTIES OTHER THAN HALIFAX, BY AGE AND DIAGNOSIS

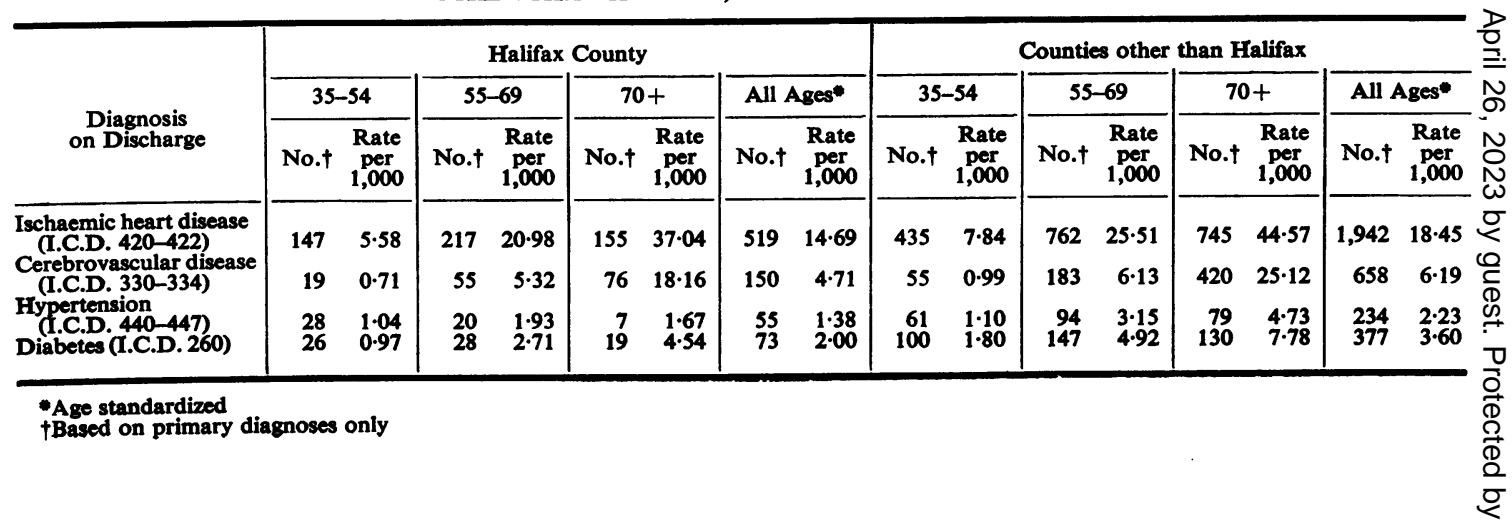


admitted for reasons other than strictly clinical (Forsyth and Logan, 1960). If such a tendency were also present in Nova Scotia, one might expect it to be more manifest in a setting where rules for hospital admission are relatively liberal than in one with more stringent rules.

\section{Discussion}

Our analysis of hospital data seems to indicate that ischaemic heart disease among women and younger subjects accounts for a larger fraction of the total morbidity due to that condition than is apparent from mortality statistics. This suggests that the likelihood of the disease having a fatal outcome is higher among men than women, and increases with age for both sexes.

The contention that the case fatality rate for ischaemic heart disease increases with age is borne out by results from several epidemiological studies. Data from Framingham indicate that fatal ischaemic heart disease accounted for $35 \%$ of new cases diagnosed among men in the age group 55-64, 32\% of those in age group $45-54$, and only $22 \%$ in age group 35-44 (Kannel and Gordon, 1969, sections

TABLE XVI

COMPARISON BETWEEN MEAN ANNUAL RATES OF FEMALES DISCHARGED IN HALIFAX COUNTY AND IN COUNTIES OTHER THAN HALIFAX, BY AGE AND DIAGNOSIS

\begin{tabular}{|c|c|c|c|c|c|c|c|c|c|c|c|c|c|c|c|c|}
\hline \multirow{3}{*}{$\begin{array}{c}\text { Diagnosis } \\
\text { on Discharge }\end{array}$} & \multicolumn{8}{|c|}{ Halifax County } & \multicolumn{8}{|c|}{ Counties other than Halifax } \\
\hline & \multicolumn{2}{|c|}{$35-54$} & \multicolumn{2}{|c|}{$55-69$} & \multicolumn{2}{|c|}{$70+$} & \multicolumn{2}{|c|}{ All Ages* } & \multicolumn{2}{|c|}{$35-54$} & \multicolumn{2}{|c|}{$55-69$} & \multicolumn{2}{|c|}{$70+$} & \multicolumn{2}{|c|}{ All Ages* } \\
\hline & No.† & $\begin{array}{c}\text { Rate } \\
\text { per } \\
1,000\end{array}$ & No.† & $\begin{array}{c}\text { Rate } \\
\text { per } \\
1,000\end{array}$ & No.t & $\begin{array}{c}\text { Rate } \\
\text { per } \\
1,000\end{array}$ & No.† & $\begin{array}{c}\text { Rate } \\
\text { per } \\
1,000\end{array}$ & No.t & $\begin{array}{c}\text { Rate } \\
\text { per } \\
1,000\end{array}$ & No.† & $\begin{array}{c}\text { Rate } \\
\text { per } \\
1,000\end{array}$ & No.† & $\begin{array}{c}\text { Rate } \\
\text { per } \\
1,000\end{array}$ & No.t & $\begin{array}{c}\text { Rate } \\
\text { per } \\
1,000\end{array}$ \\
\hline $\begin{array}{l}\text { Ischaemic heart disease } \\
\text { (I.C.D. 420-422) } \\
\text { Cerebrovascular disease } \\
\text { (I.C.D. 330-334) }\end{array}$ & 13 & $\begin{array}{l}1.51 \\
0.48\end{array}$ & 95 & $\begin{array}{l}8 \cdot 71 \\
3 \cdot 67\end{array}$ & 127 & $22 \cdot 73$ & 263 & $6 \cdot 82$ & 162 & $\begin{array}{l}2.91 \\
0.90\end{array}$ & 434 & $\begin{array}{r}15 \cdot 30 \\
4 \cdot 55\end{array}$ & 704 & $\begin{array}{l}36 \cdot 57 \\
19 \cdot 85\end{array}$ & $\begin{array}{r}1300 \\
561\end{array}$ & $\begin{array}{r}11 \cdot 60 \\
4 \cdot 88\end{array}$ \\
\hline $\begin{array}{l}\text { Hypertension } \\
\text { (I.C.D. 440-447) } \\
\text { Diabetes (I.C.D. 260) }\end{array}$ & $\begin{array}{l}37 \\
34\end{array}$ & $\begin{array}{l}1 \cdot 36 \\
1 \cdot 25\end{array}$ & $\begin{array}{l}18 \\
44\end{array}$ & $\begin{array}{l}1 \cdot 65 \\
4 \cdot 03\end{array}$ & 22 & $\begin{array}{l}3 \cdot 94 \\
6 \cdot 26\end{array}$ & $\begin{array}{r}77 \\
112\end{array}$ & $\begin{array}{l}1 \cdot 85 \\
2 \cdot 79\end{array}$ & $\begin{array}{l}109 \\
138\end{array}$ & $\begin{array}{l}1.95 \\
2.47\end{array}$ & $\begin{array}{l}137 \\
252\end{array}$ & $\begin{array}{l}4 \cdot 83 \\
8 \cdot 89\end{array}$ & $\begin{array}{l}180 \\
251\end{array}$ & $\begin{array}{r}9 \cdot 35 \\
13 \cdot 04\end{array}$ & $\begin{array}{l}426 \\
641\end{array}$ & $\begin{array}{l}3 \cdot 90 \\
5 \cdot 89\end{array}$ \\
\hline
\end{tabular}

- Age standardized

tBased on primary diagnoses only

TABLE XVII

COMPARISON BETWEEN PROPORTIONS OF PATIENTS DISCHARGED ALIVE IN HALIFAX COUNTY AND IN COUNTIES OTHER THAN HALIFAX, BY AGE, SEX AND DIAGNOSIS

\begin{tabular}{|c|c|c|c|c|c|c|c|c|c|c|c|c|c|c|c|c|}
\hline \multirow{3}{*}{ Diagnosis on Discharge } & \multicolumn{8}{|c|}{ Males ( $\%$ discharged alive) } & \multicolumn{8}{|c|}{ Females ( $\%$ discharged alive) } \\
\hline & \multicolumn{4}{|c|}{ Halifax County } & \multicolumn{4}{|c|}{ Other Counties } & \multicolumn{4}{|c|}{ Halifax County } & \multicolumn{4}{|c|}{ Other Counties } \\
\hline & $35-54$ & $55-69$ & $70+$ & All & $35-54$ & $55-69$ & $70+$ & Ages* & $35-54$ & $55-69$ & $70+$ & Ages* & $35-54$ & $55-69$ & $70+$ & Ages \\
\hline $\begin{array}{l}\text { Ischaemic heart disease } \\
\text { (I.C.D. 420-422) } \\
\text { Cerebrovascular disease }\end{array}$ & 90 & 83 & 69 & 84 & 93 & 86 & 73 & 87 & 95 & 81 & 74 & 87 & 94 & 88 & 78 & 89 \\
\hline (I.C.D. 330-334) & 74 & 71 & 64 & 71 & 78 & 81 & 62 & 76 & 74 & 77 & 62 & 73 & 80 & 77 & 67 & 77 \\
\hline $\begin{array}{l}\text { (I.C.D. 440-447) } \\
\text { Diabetes (I.C.D. 260) }\end{array}$ & $\begin{array}{l}98 \\
96\end{array}$ & $\begin{array}{l}97 \\
96\end{array}$ & $\begin{array}{l}90 \\
95\end{array}$ & $\begin{array}{l}96 \\
96\end{array}$ & $\begin{array}{l}95 \\
98\end{array}$ & $\begin{array}{l}99 \\
98\end{array}$ & $\begin{array}{l}90 \\
94\end{array}$ & $\begin{array}{l}95 \\
97\end{array}$ & $\begin{array}{r}99 \\
100\end{array}$ & $\begin{array}{r}100 \\
95\end{array}$ & $\begin{array}{l}94 \\
91\end{array}$ & $\begin{array}{l}98 \\
97\end{array}$ & $\begin{array}{l}99 \\
99\end{array}$ & $\begin{array}{l}98 \\
98\end{array}$ & $\begin{array}{l}93 \\
95\end{array}$ & $\begin{array}{l}97 \\
98\end{array}$ \\
\hline
\end{tabular}

- Age standardized

TABLE XVIII

COMPARISON BETWEEN MALE TO FEMALE RATIOS FOR RATES OF PERSONS DISCHARGED IN HALIFAX COUNTY AND IN COUNTIES OTHER THAN HALIFAX, BY AGE AND DIAGNOSIS

\begin{tabular}{|c|c|c|c|c|c|c|c|c|}
\hline \multirow{3}{*}{ Diagnosis on Discharge } & \multicolumn{8}{|c|}{ Male to Female Ratios (Rates) } \\
\hline & \multicolumn{4}{|c|}{ Halifax County } & \multicolumn{4}{|c|}{ Counties other than Halifax } \\
\hline & $35-54$ & $55-69$ & $70+$ & All Ages" & $35-54$ & $55-69$ & $70+$ & All Ages* \\
\hline $\begin{array}{l}\text { Ischaemic heart disease (I.C.D. 420-422) } \\
\text { Cerebrovascular disease (I.C.D. 330-334) } \\
\text { Hypertension (I.C.D. 440-447) } \\
\text { Diabetes (I.C.D. 260) }\end{array}$ & $\begin{array}{l}3.63 \\
1.48 \\
0.76 \\
0.78\end{array}$ & $\begin{array}{l}2 \cdot 41 \\
1.45 \\
1.17 \\
0.67\end{array}$ & $\begin{array}{l}1.63 \\
1.19 \\
0.42 \\
0.73\end{array}$ & $\begin{array}{l}2 \cdot 15 \\
1 \cdot 28 \\
0 \cdot 75 \\
0.72\end{array}$ & $\begin{array}{l}2.69 \\
1.10 \\
0.56 \\
0.73\end{array}$ & $\begin{array}{l}1.67 \\
1.35 \\
0.65 \\
0.55\end{array}$ & $\begin{array}{l}1.22 \\
1.27 \\
0.51 \\
0.60\end{array}$ & $\begin{array}{l}1.59 \\
1.27 \\
0.57 \\
0.61\end{array}$ \\
\hline
\end{tabular}

-Age standardized 
$10,13,14)$. The trend is less clear for women. The data also seem to corroborate that ischaemic heart disease is less likely to be fatal in women than in men (Ibid). The lower case fatality observed in women seems to be due to the fact that angina pectoris, a relatively benign condition, accounts for a higher proportion of all cases of ischaemic heart disease in them than it does in men (Kannel and Gordon, 1969, sections 10 and 12). However, evidence from another study (Shapiro, Weinblatt, Frank, and Sager, 1969) suggests that this tendency to develop relatively mild forms of ischaemic heart disease is not restricted to angina pectoris. Higher male to female ratios were found for cases of infarct classified as 'probable', many of whom died within 48 hours, than for cases classified as 'possible' infarcts, which tended to be less severe.

The present study suggests that men have a somewhat higher risk of developing cerebrovascular disease than women. A similar impression is conveyed by at least two community-based surveys. Preliminary results from Rochester, Minnesota (Kurland, Choi, and Sayre, 1967) show male to female ratios of the same order of magnitude as that observed in our data (approximately 1.3). Similar ratios are found in the Framingham data for age groups 45-54 and 55-64 (Kannel and Gordon, 1969, section 15). It is worth noting that sex ratios of this order, although considerably smaller than those occurring for myocardial infarction, are nevertheless not markedly different from the ratios seen for angina pectoris.

The finding that morbidity and, to a lesser extent, mortality from hypertension and diabetes are higher for women than for men is in agreement with observations from other sources. British (Registrar General, 1966-68) and American (National Center for Health Statistics, 1966a) mortality statistics show higher death rates from these conditions for women than for men in older age groups. Morbidity surveys in which sufficient cases were uncovered to allow detailed analyses also show an excess of diabetes and hypertension among women. A higher prevalence of diabetes among women than men was observed in Tecumseh (Epstein et al., 1965). Similar results were obtained in the U.S. National Health Survey (National Center for Health Statistics, 1967), while data from the Health Examination Survey (National Center for Health Statistics, 1966b) indicate that in persons over 50 this is also true for hypertension and hypertensive heart disease.

Hypertension is well established as a risk factor with regard to ischaemic heart disease (Morris and Gardner, 1969), and it has long been recognized that diabetes predisposes to the various manifestations of atherosclerosis (Joslin, 1927). Thus, the increased prevalence of hypertension and diabetes observed among women may be due partly to the selectivez removal of men with these two conditions through death from ischaemic heart disease. It is interesting to note in this connexion that a recent observations? from the Tecumseh study (Deutscher, Ostrander, and Epstein, 1970) suggests that, in the generalo population, a disproportionate number of premature $\frac{\bar{c}}{\bar{c}}$ deaths from ischaemic heart disease among males $s_{\varrho}^{\mathbb{D}}$ occur in diabetics.

\section{SUMmary}

Hospital discharge data generated through the Canadian Hospital Insurance Programme were $\vec{\omega}$ compared to mortality data with respect to age and sex trends in four inter-related conditions-ischae- $\frac{D}{?}$ mic heart disease, cerebrovascular disease, hyper-i tension, and diabetes. As expected, in-patient morbidity due to ischaemic heart disease increased ${ }_{\infty}$ with age and was higher for men than for women. + However, the morbidity among younger subjects $?$ was greater than anticipated on the basis of the age distribution found in mortality statistics. This suggests that case fatality rates for ischaemic heart_ disease increase with age. Similarly, larger male to 9 female ratios were found in mortality than $\oint_{n}$.morbidity data, suggesting that the case fatality rate응 is higher in men than in women. Male to females ratios for in-patient morbidity due to cerebrovascu- $-\bar{\partial}$ lar disease were above unity (age-adjusted ratio 1.3), suggesting that men have a somewhat higher risk of developing such accidents than women. The reverse $\overrightarrow{\vec{\prime}}$ occurred in the case of hypertension and diabetes. 3 Discharge rates were higher for women than for men. This strongly suggests that these conditions? are more prevalent among the former. The increased prevalence of hypertension and diabetes among women may be due to selective removal of men with ${ }_{\vec{\sigma}}$ these conditions through premature death from? ischaemic heart disease.

We wish to thank Dr. G. G. Simms, director of the Nova Scotia Hospital Insurance Commission, and Dr.음 P. C. Gordon, Chairman of the Department of Pre- $>$ ventive Medicine, Dalhousie University, for their support. We also thank Mrs. M. Harnish for providing statistical assistance.

This study was assisted by funds provided by the $N$ Research Position in Epidemiology Grant No. 602-7-110 N of the National Health Grants Programme, Department $\omega$ of National Health and Welfare, Canada.

\section{REFERENCES}

Deutscher, S., Ostrander, L. D., and EPSTEIN, F. H.. (1970). Familial factors in premature coronary heart 0 disease-A preliminary report from the Tecumseho Community Health Study. Amer. J. Epidem. 91, 233. 
Epstein, F. H., Francis, T. JR., Hayner, N. S., Johnson, B. C., KJelsberg, M. O., Napier, J. A., Ostrander, L. D. Jr., Payne, M. W., and Dodge, H. J. (1965). Prevalence of chronic diseases and distribution of selected physiologic variables in a total community, Tecumseh, Michigan. Amer. J. Epidem. 81, 307.

Forsyth, G., and Logan, R. F. L. (1960). The Demand for Medical Care. In A Study of the Case-load in the Barrow and Furness Group of Hospitals. Oxford University Press, London.

Joslin, E. P. (1927). Arteriosclerosis and diabetes. Ann. clin. Med., 5, 1061.

KANNEL, W. B., and Gordon, T., Editors (1969). The Framingham Study: An Epidemiological Investigation of Cardiovascular Disease. U.S., D.H.E.W., Public Health Service, National Institutes of Health, Superintendent of Documents, U.S. Government Printing Office, Washington, D.C. 20402.

Kurland, L. T., Choi, N. W., and Sayre, G. P. (1967). Current status of the epidemiology of cerebrovascular disease. In Stroke Rehabilitation: Basic Concepts and Research Trends, edited by W. S. Fields and W. A. Spencer, pp. 3-22.
MorRIS, J. N., and GARDNER, M. J. (1969). Epidemiology of ischaemic heart disease. Amer. J. Med., 46, 674.

National Center for Health Statistics (1966a). Mortality trends in the United States, 1954-1963. Vital and Health Statistics. PHS Pub. No. 1000-Series 20No. 2. Public Health Service. Washington, U.S. Government Printing Office.

- (1966b). Hypertension and hypertensive heart disease in adults, United States: 1960-1962. Vital and Health Statistics. PHS Pub. No. 1000-Series 11No. 13. Public Health Service. Washington, U.S. Government Printing Office.

(1967). Characteristics of persons with diabetes, United States: July 1964-June 1965. Vital and Health Statistics. PHS Pub. No. 1000-Series 10-No. 40. Public Health Sorvice. Washington, U.S. Government Printing Office.

Registrar General's Statistical Reviews of England AND WaLeS (1966-1968). H.M.S.O., London.

Shapiro, S., Weinblatt, E., Frank, C. W., and Sager, R. V. (1969). Incidence of coronary heart disease in a population insured for medical care (HIP). Amer. J. publ. Hlth, 59, No. 6, Part II, supplement to the June issue. 